\title{
Performance of an on-farm anaerobic digester using dairy cow slurry as the sole feedstock
}

J P Frost, S R Gilkinson

Agri-Food and Biosciences Institute, Hillsborough, Northern Ireland, United Kingdom

Email: peter.frost@afbini.gov.uk

Introduction Anaerobic digestion (AD) is employed widely across the world to produce a source of renewable energy as biogas (mainly methane). However, there has been only limited uptake of AD in the UK, particularly at farm level. The aim of this study was to assess the performance of on-farm $\mathrm{AD}$, using fresh dairy cow slurry as the sole feedstock.

Materials and methods An anaerobic digester at AFBI-Hillsborough was used to study the performance of AD using farm based organic materials as feedstock. The digester was a $660 \mathrm{~m}^{3}$ insulated above ground tank, maintained at an average of $39^{\circ} \mathrm{C}$ (s.d. 2.2), discharged and fed hourly and mixed via biogas recirculation. Slurry from dairy cows at AFBI was the sole feed at approximately $20 \mathrm{t} \mathrm{d}^{-1}$. Process data were automatically recorded every 30 seconds throughout the 20 week recording period (12 December 2008 to 1 May 2009). Biogas composition was recorded once daily with a hand held gas meter (Gas Data GFM400, UK). Feedstock and digestate were sampled daily, bulked weekly and analysed for DM, ash, N, $\mathrm{NH}_{3}-\mathrm{N}, \mathrm{P}$ and $\mathrm{K}$. Volatile solids (VS) contents were calculated as the difference between DM and ash contents. Hydraulic retention time was a nominal 27 days (s.d. 1.0).

Results The mean biogas composition during the recording period was 0.57 methane (s.d. 0.028 ), 0.37 carbon dioxide (s.d. 0.025 ) and 0.002 hydrogen sulphide (s.d. 0.0004). The average weekly feedstock temperature was $7.7^{0} \mathrm{C}$ (range $4.6-$ $11.4^{0} \mathrm{C}$ ). The proportion of gross biogas energy required to maintain digester temperature was 0.39 (range $0.30-0.51$ ). Table 1 summarises digester performance.

Table 1 Summary of daily digester performance using dairy cow slurry as feedstock over a 20 week period

\begin{tabular}{llll}
\hline \hline Parameter & Unit & Value & Standard deviation \\
\hline Slurry loading rate & $\mathrm{t} \mathrm{d}^{-1}$ & 19.8 & 0.86 \\
VS loading rate & $\mathrm{kg} \mathrm{VS} \mathrm{m}^{-3} \mathrm{~d}^{-1}$ & 2.36 & 0.146 \\
Biogas produced & $\mathrm{Nm}^{3} \mathrm{~d}^{-1}$ & 310 & 31.4 \\
Biogas productivity & $\mathrm{Nm}^{3} \mathrm{~m}^{-3}$ of digester d & 0.055 \\
Biogas yield & $\mathrm{Nm}^{3} \mathrm{~kg}^{-1} \mathrm{VS}$ & 0.58 & 0.022 \\
Methane yield & $\mathrm{Nm}^{3} \mathrm{~kg}^{-1} \mathrm{VS}$ & 0.25 & 0.013 \\
Gross energy in biogas & $\mathrm{kWh} \mathrm{d}$ & 0.14 & 201 \\
Energy to maintain & $\mathrm{AD} \mathrm{kWh} \mathrm{d}^{-1}$ & 1758 & 129 \\
temperature & & 689 &
\end{tabular}

temperature

The digester produced $0.14 \mathrm{Nm}^{3}$ methane $\mathrm{kg}^{-1} \mathrm{VS}$ in feedstock (Table 1) equivalent to $89 \mathrm{kWh} \mathrm{t}^{-1}$ of feedstock. This is an extremely useful source of renewable energy. This overall performance was very similar to that predicted by Frost et al. (2006), though was less than predictions of some AD suppliers e.g. approximately 0.16 less methane per unit of VS in the feedstock. Furthermore, the AFBI AD produced 0.61 less methane per unit of VS than the average of 41 Austrian digesters reported by Braun et al. (2009). The majority of these Austrian digesters used energy crops as the major component of their feedstock and had hydraulic retention times that were on average about five times longer than in the AFBI AD. Both of these factors would account for the higher degradation of VS in Austria (0.83) than at AFBI (0.24). In the AFBI digester approximately 0.20 of the DM and 0.24 of the VS were degraded (Table 2). The total N, P and K concentrations of the digestate were not significantly $(\mathrm{P}>0.05)$ affected by digestion (Table 2$)$. However, the crop available nitrogen $\left(\mathrm{NH}_{3}-\mathrm{N}\right)$ concentration of the digestate was significantly $(\mathrm{P}<0.001)$ increased by 0.16 relative to the feedstock.

Table 2 Summary of nutrient concentrations in dairy cow slurry feedstock and digestate over a 20 week period

\begin{tabular}{lllll}
\hline \hline $\mathrm{g} \mathrm{kg}^{-1}$ fresh & Feedstock & Digestate & s.e.d. & $\mathrm{P}$ \\
\hline $\mathrm{DM}$ & 81.1 & 64.9 & 0.86 & $<0.001$ \\
$\mathrm{pH}$ & 7.66 & 8.05 & 0.059 & $<0.001$ \\
Total N & 4.12 & 4.10 & 0.062 & 0.682 \\
$\mathrm{NH}_{3}-\mathrm{N}$ & 2.26 & 2.63 & 0.055 & $<0.001$ \\
Total P & 0.59 & 0.61 & 0.124 & 0.102 \\
Total K & 4.52 & 4.52 & 0.134 & 0.992 \\
VS & 63.5 & 48.2 & 0.77 & $<0.001$ \\
\hline \hline
\end{tabular}

Conclusions Dairy cow slurry is a useful source of renewable energy. The crop available nitrogen in the digestate, compared to the feedstock, was enhanced.

\section{References}

Frost P, Gilkinson S and Buick J. 2006. www.actionrenewables.org, accessed 13 October 2009.

Braun R, Weiland P and Wellinger A. 2009. Biogas from Energy Crop Digestion. www.iea-biogas.net, accessed 11 January 2010 . 